\title{
Reproductive efficiency methods and their relationship with siliqua production in Mustard
}

\author{
A. Islam and M. S. A. Fakir \\ Department of Crop Botany, Bangladesh Agricultural University, Mymensingh-2202, Bangladesh \\ E-mail: fakirmsa@gmail.com
}

\begin{abstract}
Five reproductive efficiency methods (REM) were evaluated under field condition to measure yield in 12 varieties of Brassica campestris L. in 2005 and 2006 at Mymensingh $\left(24^{\circ} 75^{\prime} \mathrm{N}\right.$ latitude and $90^{\circ} 50^{\prime} \mathrm{E}$ longitude) based on flower and siliqua production and total reproductive unit (TRU- number of buds, flowers, siliqua and number of empty pedicels). Five REMs were estimated and they were REM-I [ (Mature siliqua $\div$ TRU) $\times 100]$; REM-II [(Mature siliqua $\div$ Flower number) $\times$ 100]; REM-III [\{(Mature siliqua + Immature siliqua) $\div$ TRU $\} \times 100]$; REM-IV[\{(Mature siliqua + Immature siliqua) $\div$ Flower number $\} \times 100]$; and REM-V [(Flower number $\div$ TRU) $\times 100]$. Siliqua number plant ${ }^{-1}$ showed positive and significant relationship with TRU ( $r=0.869^{* *}$ and $0.713^{* *}$ in 2005 and 2006, respectively) and flower number ( $r=0.984^{* *}$ and $0.834^{* *}$ in 2005 and 2006, respectively). Path analysis revealed that there exited high positive direct effect of siliqua number with sink (flower) number (0.655 and 0.714 in 2005 and 2006, respectively) and TRU (0.201 and 0.252 in 2005 and 2006, respectively). Among the REMs, REM-III had high positive direct effect with only siliqua production (1.331 and 0.899 in 2005 and 2006, respectively). For the first time we report REMs in mustard that number of sink production is an important index of siliqua yield and REM-III appears more reliable method of estimating RE in Brassica campestris.
\end{abstract}

Keywords: Brassica campestris, Siliqua, Reproductive efficiency, Correlation, Path analysis

\section{Introduction}

Reproductive efficiency (RE) in mustard (Brassica campestris L.) is the magnitude of flower production and propensity of fruit formation that determines final yield. It is the total reproductive unit (TRU) of a plant which includes total number of buds/ plant i.e. the sum of number of buds, opened flowers, fruits and number of abscised reproductive structures (Fakir et al., 1998). In Brassica campestris, flowering proceeds acropetally in the racemes and produces 174 to 223 flowers plant $^{-1}$ (Khatun, 2004). In mustard, shedding of buds, flower and even immature siliqua is often observed. The rate of flowers which form siliqua is only about 45\% (Tayo and Morgan, 1975). Khatun (2004) and Islam (2006) on the other hand, observed 50 to $80 \%$ fruit set in 20 different varieties of mustard under climatic condition of Mymensingh $\left(24^{\circ} 75^{\prime} \mathrm{N}\right.$ latitude and $90^{\circ} 50^{\prime} \mathrm{E}$ longitude). Variation of degree of fruit set may be due to differences in genotypes and location. Very little research information is available on RE in mustard at abroad (Tayo and Morgan, 1975; Ferranti et al., 1994) and at Bangladesh (Khatun, 2004 and Shil, 2005). In pigeonpea, pod production determines seed yield which depends on genotype, location and methods of RE assessment (Fakir et al., 1998). Miri (2008) conducted a field experiment to determine morphological and physiological traits associated with yield improvement in rapeseed in 16 cultivars. The results of correlation and path analysis indicated that number of siliqua plant ${ }^{-1}$ and fruit formation was significantly correlated with the grain yield. In the yield components, days to flowering and number of siliqua plant ${ }^{-1}$ were correlated significantly with grain yield (Ozer et al., 1999). A significant correlation was also observed between siliqua number plant $^{-1}$ and grain yield in $B$. napus and B. compestris (Thurling, 1974). This showed that among yield components number of siliqua had greatest, and seed siliqua ${ }^{-1}$ and seed weight had weak influence on grain yield. Siliqua production is a complex character that can be determined by several components reflecting positive or negative effects upon the characters as determined by correlation study, whereas it is important to examine the contribution of each of the various components on final yield to emphasize the greatest influence by path analysis. Information on the association of plant characters with siliqua production is of great importance in selecting a desirable genotype. Researches were carried out to determine relationships between seed yield and yield components using correlation and path coefficient analysis in mustard/rapeseed at abroad (Ozer et al., 1999; Tunçturk and Çyftiçy, 2007; Miri, 2008). Further different reproductive efficiency methods (REMs), i.e. ratio of number of fruits or pods to total numbers of flowers and or buds, have been employed to measure final yield in peanut (Coffelt et al, 1989), pigeonpea (Fakir et al., 1998a), tomato (Khalid, 1999), 
country bean (Fakir et al., 2000) and mungbean (Fakir et al., 2011) but no such published data is available in Mustard in world literature. Therefore, the experiment was carried out to develop and compare reproductive efficiency methods (REMs), and to investigate relationship of REMs with sink (flower) and siliqua production in twelve genotypes of Brassica campestris $L$.

\section{Materials Methods}

Seeds of six mustard (Brassica campestris L.) varieties (BARI sarisa 6, Agrani, Sonali, BINA sarisa 6, BARI sarisa 10 and BARI sarisa 11) in 2005 and also six varieties (BINA sarisa 6, Safal, Agroni, BARI sarisa 6, BARI sarisa 9, BARI sarisa 12) in 2006 were collected from Bangladesh Agricultural Research Institute and Bangladesh Institute of Nuclear Agriculture.

Two field experiments were conducted on a silt clay loam textured soil having $p^{H}$ value 7.34 at the field laboratory of the Department of Crop Botany, Bangladesh Agricultural University, Mymensingh between November 2004 and March 2005, and between November 2005 and March 2006. Seeds were hand sown on $10 \mathrm{Nov}, 2004$ and $14 \mathrm{Nov}$. in 2005. Seeds were sown $5 \mathrm{~cm}$ apart in a line. The line to line distance was $20 \mathrm{~cm}$. Seeds were continuously sown in line and was thinned to one seedling between 10 and 15 days after emergence maintaining a distance of $10 \mathrm{~cm}$ within plants. A randomised complete block design with three replications was followed using $2 \mathrm{~m}^{2}$ plots. The plot to plot distance was $0.5 \mathrm{~m}$ and block to block distance was $0.8 \mathrm{~m}$. In both the years, the experimental area was fertilized @ $125 \mathrm{~kg}^{\text {Urea ha-1 }}{ }^{-1}, 160$ $\mathrm{kg} \mathrm{TSP} \mathrm{ha}{ }^{-1}, 80 \mathrm{~kg} \mathrm{MP} \mathrm{ha}{ }^{-1}, 180 \mathrm{~kg}$ Gypsum ha-1 before sowing. Additional $125 \mathrm{~kg}$ urea was top dressed just 20 days before flowering. The crops were irrigated twice at 24 days after mergence (DAE) and 50 DAE in both years and also protected against the pests with Rovral @ $2 \mathrm{gL}^{-1}$ in both years.

The experimental plots were harvested separately when $70-80 \%$ siliqua reached maturity (straw coloured). Prior to harvesting fifteen plants, five each from three replications, were selected randomly for collecting data on different reproductive parameters. These were: siliqua plant ${ }^{-1}$ (no.); total number of potential siliqua plant ${ }^{-1}$ or total number of buds plant ${ }^{-1}$ i.e. total reproductive unit (TRU) plant ${ }^{-1}$ (no. of mature siliqua + no. of immature siliqua + no. of unfertilized siliqua + no. of empty pedicel/scar); opened flower (henceforth flower) was counted by summing up all the flowers that set siliqua i.e. flower plant ${ }^{-1}=$ (no. of mature siliqua + no. of immature siliqua + no. of unfertilized siliqua). Five reproductive efficiency methods (REM) were developed and used in this present study simulating the methods of Coffelt et al. (1989). These are: i) REM-I = (number of mature siliqua $\div$ TRU) $\times 100$; ii) REM-II = (number of mature siliqua $\div$ flower number $) \times 100$; iii $)$ REM-III $=\{($ number of mature siliqua + number of immature siliqua $) \div$ TRU $\} \times 100$; iv) REM-IV $=\{($ number of mature siliqua + number of immature siliqua $) \div$ flower number $\}$ $\times 100$; and $v)$ REM-V $=($ flower number $\div$ TRU $) \times 100$. The first four formulae are $\%$ siliqua set while the last one is \% flower production.

Path coefficient analysis was carried out to determine correlation coefficient $(r)$ between dependent and independent variables, and $r$ was partitioned into direct and indirect effects using path analysis (Singh and Choudhury, 1985).

\section{Results and Discussion}

Association of characters: In 2005, siliqua number had significant positive correlation with TRU plant $^{-1}$ $(r=0.869, P \leq 0.01)$, flower number plant ${ }^{-1}(r=0.984, P \leq 0.01)$, REM-III $(r=0.666 P \leq 0.01)$ and REM-IV $(r=0.826, P \leq 0.01)$ (Table 1). In 2006, siliqua number also had positive correlation with TRU ( $r=0.713$, $P \leq 0.01)$ and flower number plant ${ }^{-1}(r=0.834, P \leq 0.01)$ (Table 1). Among the associations of REMs, REM-V showed significant positive correlation with REM-I $(r=0.547, \mathrm{P} \leq 0.05)$ and REM-III $(r=0.917, \mathrm{P} \leq 0.01)$ in 2005 and also with REM-I ( $r=0.636, P \leq 0.05)$ and REM-III ( $r=0.798, P \leq 0.01)$ in 2006 (Table 1). In 2005, REM-IV also showed significant positive correlation with REM-III $(r=0.794, P \leq 0.01)$ and flower number $(r=0.766, P \leq 0.01)$ and TRU plant ${ }^{-1}(r=0.580, P \leq 0.05)$. But in 2006, REM-IV showed positive and significant correlation with REM-III $(r=0.835, \mathrm{P} \leq 0.01)$, REM-II $(r=0.668, \mathrm{P} \leq 0.01)$ and REM-I $(r=0.778$, $P \leq 0.01)$ and negative significant correlation with TRU ( $r=-0.473, P \leq 0.01)$. REM-III, in 2005, showed positive relation with all the characters and significant correlation with flower number $(r=0.610, P \leq 0.05)$. Again REM-III, in 2006, had positive and significant correlation with REM-I ( $r=0.841, P \leq 0.01)$ and REM-II $(r=0.543, P \leq 0.05)$ and negative correlation with flower number $(r=-0.271)$ and TRU plant ${ }^{-1}(r=-0.435)$. 
REM-II showed highly significant positive correlation with REM-I in both the years $(r=0.803, P \leq 0.01$ in 2005; $r=0.682, P \leq 0.01$ in 2006) (Table 1). REM-I did not show significant relationship with flower number and TRU in either year. For flower number, positive and significant correlation was obtained with TRU plant $^{-1}$ in both years $(r=0.904, P \leq 0.01$ in 2005 and $r=0.952, P \leq 0.01$ in 2006) (Table 1).

Table 1. Correlation co-efficient among different reproductive parameters in six varieties of Brassica campestris in 2005 and 2006

\begin{tabular}{|c|c|c|c|c|c|c|c|c|}
\hline Parameter & $\begin{array}{c}\mathrm{TRU}^{\dagger} / \\
\text { plant (no.) }\end{array}$ & $\begin{array}{l}\text { Flower }^{\dagger \dagger} \\
\text { /plant (no.) }\end{array}$ & $\mathrm{REM}^{\text {t†† }}$ & REM-II & REM-III & REM-IV & REM-V & $\begin{array}{l}\text { Siliqua/ plant } \\
\text { (no.) }\end{array}$ \\
\hline & & & & \multicolumn{2}{|c|}{2005} & & & \\
\hline TRU & 1.00 & & & & & & & \\
\hline Flower no. & $0.904^{* *}$ & 1.00 & & & & & & \\
\hline REM-I & -0.023 & 0.220 & 1.00 & & & & & \\
\hline REM-II & 0.090 & 0.119 & $0.803^{* *}$ & 1.00 & & & & \\
\hline REM-III & 0.232 & $0.610^{*}$ & 0.437 & 0.053 & 1.00 & & & \\
\hline REM-IV & $0.580^{*}$ & $0.766^{* *}$ & 0.178 & 0.132 & $0.794^{* *}$ & 1.00 & & \\
\hline REM-V & -0.063 & 0.364 & $0.547^{*}$ & 0.035 & $0.917^{\star \star}$ & 0.498 & 1.00 & \\
\hline \multirow[t]{2}{*}{ Siliqua/plant } & $0.896^{\star *}$ & $0.984^{* *}$ & 0.222 & 0.138 & $0.666^{\star *}$ & $0.826^{\star *}$ & 0.398 & 1.00 \\
\hline & & & & \multicolumn{2}{|c|}{2006} & & & \\
\hline TRU & 1 & & & & & & & \\
\hline Flower no. & $0.952^{* *}$ & 1.00 & & & & & & \\
\hline REM-I & -0.348 & -0.180 & 1.00 & & & & & \\
\hline REM-II & -0.109 & -0.010 & $0.682^{* \star}$ & 1.00 & & & & \\
\hline REM-III & -0.435 & -0.271 & $0.841^{* *}$ & $0.543^{*}$ & 1.00 & & & \\
\hline REM-IV & $-0.473^{*}$ & -0.394 & $.778^{\star *}$ & $0.668^{* *}$ & $0.835^{\star *}$ & 1.00 & & \\
\hline REM-V & -0.231 & -0.040 & $0.636^{* *}$ & 0.224 & $0.798^{* *}$ & 0.363 & 1.00 & \\
\hline Siliqua/plant & $0.713^{* *}$ & $0.834^{* *}$ & 0.284 & 0.308 & 0.236 & 0.047 & 0.337 & 1.00 \\
\hline
\end{tabular}

${ }^{\dagger}$ TRU: Number of mature and immature siliqua + number of unfertilized siliqua + number of flowers + number of scars; ${ }^{\dagger \dagger}$ Flower no.: Number of mature and immature siliqua + number of unfertilized siliqua; ${ }^{\dagger+t:}$ REM= Reproductive efficiency method; ${ }^{*},{ }^{* *}=$ Significant at 5 and $1 \%$ level of probability respectively; Number of observations $=18(6$ varieties $\times 3$ replications)

The association between siliqua numbers, TRU and flower plant ${ }^{-1}$ was significant in both the years. These results revealed the importance of the number TRU and flower plant ${ }^{-1}$ as a criterion for mustard yield improvement. Therefore, selection for increasing siliqua number through these traits might be more successful. Regarding REMs, correlation study revealed that in general, the association between siliqua number and REMs showed consistent trend in the two seasons. It was positively correlated with all REMs. However, the highest and significant correlation coefficients were found for REM-III and REM-IV for 2005. Interestingly none of the REMs showed significant relationship with siliqua number in 2005 . This may be due some other factors remained unaccounted for.

Path coefficient analysis: The direct effects of TRU plant ${ }^{-1}$ on siliqua production were all positive and of high importance and in simple correlation study, this trait was positively and significantly associated with siliqua production in both the years (Table 2). In both the years, the indirect effect of TRU plant $^{-1}$ on siliqua plant ${ }^{-1}$ through its association with flower plant $^{-1}$ was 0.592 and 0.680 (in 2005 and 2006, respectively); and with REM-V was 0.037 and 0.067 (in 2005 and 2006, respectively) indicating a positive relationship of siliqua/plant with flower/plant and REM-V.

The direct effects of flower plant ${ }^{-1}$ on siliqua production were 0.655 and 0.714 in 2005 and 2006, respectively indicating that siliqua production can be improved by increasing percentage of siliqua set. In simple correlation study, this trait also showed positive and significant association with siliqua production in both the years (Table 2). The indirect effect of flower plant ${ }^{-1}$ on siliqua plant ${ }^{-1}$ through its association with TRU plant ${ }^{-1}$ was positive (0.181 and 0.240 in 2005 and 2006, respectively).

Further, REM-I was positively correlated with siliqua plant $^{-1}$ in both the years (Table 1 ). Based on path analysis, however, the direct effect of this trait was negative in 2005 but positive in 2006 . The indirect effect of REM-I on siliqua plant ${ }^{-1}$ via REM-II (0.239 and 0.024 in 2005 and 2006, respectively) and REM-III ( 0.580 and 0.756 in 2005 and 2006, respectively) was found positive. The direct effects of REM-II on 
siliqua production were all positive and in simple correlation study, this trait was positively associated with siliqua production in both the years (Table 1). The direct effect of REM-II was positive in both the years but the indirect effects of REM-II on siliqua plant ${ }^{-1}$ through its association with other character except REM-III (0.067 and 0.488 in 2005 and 2006, respectively) were negligible and inconsistent (Table 2). The effect of REM-III on siliqua plant ${ }^{-1}$ had the highest positive direct effect in both the years (1.331in 2005 and 0.899 in 2006). In simple correlation this trait was positively associated with siliqua plant ${ }^{-1}$ in both 2005 and 2006. These results imply that REM-III i.e. \% siliqua set to TRU appears to be an important determinant of siliqua production. The indirect effect of REM-III on siliqua plant ${ }^{-1}$ through its association with other characters varied in both the years. The direct effects of REM-IV on siliqua plant ${ }^{-1}$ were all negative whereas, in simple correlation study, this trait was positively associated with siliqua plant ${ }^{-1}$ in both the years. The usefulness of path-coefficient analysis is apparent. The indirect effect of REM-IV on siliqua production through its association with REM-III was positive (1.057 and 0.751 in 2005 and 2006, respectively). The indirect effects of the other traits were inconsistent. Again, the direct effects of REM-V on siliqua plant $^{-1}$ were all negative although in simple correlation study, this trait showed positive association with siliqua plant ${ }^{-1}$ in both the years. The indirect effect of REM-IV on siliqua production through its association with REM-III was positive (1.220 and 0.718 in 2005 and 2006, respectively). The indirect effect of the other traits was inconsistent.

Table 2. Path-coefficient values estimated for siliqua production and reproductive efficiency methods in 2005 and 2006

\begin{tabular}{|c|c|c|}
\hline \multirow[b]{2}{*}{ Pathways of association } & \multicolumn{2}{|c|}{ Values estimated in } \\
\hline & 2005 & 2006 \\
\hline \multicolumn{3}{|l|}{ Siliqua production vs.TRU ${ }^{\dagger}$ plant $^{-1}$ (no.) } \\
\hline Direct effect & 0.201 & 0.252 \\
\hline Indirect effect via Flower ${ }^{\dagger \dagger}$ plant $^{-1} \quad$ (no.) & 0.592 & 0.680 \\
\hline Indirect effect via REM-I & 0.008 & -0.067 \\
\hline Indirect effect via REM-II & 0.032 & -0.003 \\
\hline Indirect effect via REM-III & 0.308 & -0.391 \\
\hline Indirect effect via REM-IV & -0.311 & 0.176 \\
\hline Indirect effect via REM-V & 0.037 & 0.067 \\
\hline Correlation, $r$ & $0.869^{* \star}$ & $0.713^{\star \star}$ \\
\hline \multicolumn{3}{|l|}{ Siliqua production vs. Flower plant ${ }^{-1}$ (no.) } \\
\hline Direct effect & 0.655 & 0.714 \\
\hline Indirect effect via TRU plant ${ }^{-1}$ (no.) & 0.181 & 0.240 \\
\hline Indirect effect via REM-I & -0.082 & -0.034 \\
\hline Indirect effect via REM-II & 0.043 & -0.0003 \\
\hline Indirect effect via REM-III & 0.812 & -0.243 \\
\hline Indirect effect via REM-IV & -0.412 & 0.147 \\
\hline Indirect effect via REM-V & -0.214 & 0.011 \\
\hline Correlation, $\mathrm{r}$ & $0.984^{\star \star}$ & $0.834^{\star \star}$ \\
\hline \multicolumn{3}{|l|}{ Siliqua production vs. REM-I } \\
\hline Direct effect & -0.372 & 0.193 \\
\hline Indirect effect via TRU plant ${ }^{-1}$ (no.) & -0.004 & -0.087 \\
\hline Indirect effect via Flower plant ${ }^{-1}$ (no.) & 0.144 & -0.128 \\
\hline Indirect effect via REM-II & 0.293 & 0.024 \\
\hline Indirect effect via REM-III & 0.580 & 0.756 \\
\hline Indirect effect via REM-IV & -0.095 & -0.290 \\
\hline Indirect effect via REM-V & -0.322 & -0.184 \\
\hline Correlation, $r$ & 0.222 & 0.284 \\
\hline \multicolumn{3}{|l|}{ Siliqua production vs. REM-II } \\
\hline Direct effect & 0.365 & 0.036 \\
\hline Indirect effect via TRU plant $^{-1}$ (no.) & 0.018 & -0.027 \\
\hline Indirect effect via Flower plant ${ }^{-1}$ (no.) & 0.077 & -0.007 \\
\hline Indirect effect via REM-I & -0.299 & 0.132 \\
\hline Indirect effect via REM-III & 0.067 & 0.488 \\
\hline Indirect effect via REM-IV & -0.071 & -0.249 \\
\hline Indirect effect via REM-V & -0.020 & -0.065 \\
\hline
\end{tabular}


Table 2. Contd.

\begin{tabular}{|c|c|c|}
\hline \multirow[b]{2}{*}{ Pathways of association } & \multicolumn{2}{|c|}{ Values estimated in } \\
\hline & 2005 & 2006 \\
\hline Correlation, $\mathrm{r}$ & 0.138 & 0.308 \\
\hline \multicolumn{3}{|l|}{ Siliqua production vs. REM-III } \\
\hline Direct effect & 1.331 & 0.899 \\
\hline Indirect effect via TRU plant $^{-1}$ (no.) & 0.046 & -0.109 \\
\hline Indirect effect via Flower plant $^{-1}$ (no.) & 0.399 & -0.193 \\
\hline Indirect effect via REM-I & -0.162 & 0.163 \\
\hline Indirect effect via REM-II & 0.018 & 0.019 \\
\hline Indirect effect via REM-IV & -0.427 & -0.311 \\
\hline Indirect effect via REM-V & -0.540 & -0.231 \\
\hline Correlation, $r$ & $0.666^{* *}$ & 0.236 \\
\hline \multicolumn{3}{|l|}{ Siliqua production vs. REM-IV } \\
\hline Direct effect & -0.537 & -0.373 \\
\hline Indirect effect via TRU plant $^{-1}$ (no.) & 0.116 & -0.119 \\
\hline Indirect effect via Flower plant $^{-1}$ (no.) & 0.501 & -0.281 \\
\hline Indirect effect via REM-I & -0.066 & 0.150 \\
\hline Indirect effect via REM-II & 0.048 & 0.024 \\
\hline Indirect effect via REM-III & 1.057 & 0.751 \\
\hline Indirect effect via REM-V & -0.293 & -0.105 \\
\hline Correlation, $r$ & $0.826^{* *}$ & 0.047 \\
\hline \multicolumn{3}{|l|}{ Siliqua production vs. REM-V } \\
\hline Direct effect & -0.589 & -0.290 \\
\hline Indirect effect via TRU plant $^{-1}$ (no.) & -0.012 & -0.058 \\
\hline Indirect effect via Flower plant $^{-1}$ (no.) & 0.238 & -0.028 \\
\hline Indirect effect via REM-I & -0.204 & 0.123 \\
\hline Indirect effect via REM-II & 0.012 & 0.008 \\
\hline Indirect effect via REM-III & 1.220 & 0.718 \\
\hline Indirect effect via REM-IV & -0.260 & -0.135 \\
\hline Correlation, $r$ & 0.398 & 0.337 \\
\hline
\end{tabular}

${ }^{\dagger}$ TRU: Number of mature siliqua + number of immature siliqua + number of unfertilized siliqua + number of scar;

${ }^{\dagger \dagger}$ Flower no: Number of mature siliqua + number of immature siliqua + number of unfertilized siliqua; ${ }^{\dagger+t: ~} \mathrm{REM}=$ Reproductive efficiency method;**: Significant at $\mathrm{P} \leq 0.01$.

Results indicated that the parameters showing the highest correlations with siliqua plant $^{-1}$ also had the largest direct effect on siliqua plant ${ }^{-1}$ except REM-IV. This variation of the results can be partly attributed to the variation in precipitation (data not shown) in the study years and using different varieties in two seasons. Yield component relationships in mustard appear, therefore, to be characterised by a strong environmental control of the type and degree of stress. In spite of different varieties used in two different seasons, yet REM-III showed the highest positive direct effect on siliqua/plant among all the REMs indicating the usefulness of the REM.

Different selection indices and REMs were applicable in Brassica campestris. Results present a useful picture of the relationships between yield components and REMs as well as allow a better understanding of yield attributes compensation. The path coefficient analysis generally confirmed the findings of the correlation analysis, but also provided additional information on component interrelationships which would not have been obtained from an examination of correlation coefficients alone (Özer et al., 1999). Positive direct effect of siliqua number on REM-III suggested that this formula may be used as a good selection criterion to estimate siliqua number and seed yield in mustard. From the two year's data it, therefore, could be concluded that REM-III i.e. ration of siliqua (number of both mature plus immature) to TRU (total number of potential siliqua or buds) appear to be more effective than other REMs in predicting siliqua yield in mustard. 


\section{References}

Coffelt, T.A., Seaton, M.L. and VanScoyoc, S.W. 1989. Reproductive efficiency of 14 Virginia type peanut cultivars. Crop Sci., 29: 1217-1220.

Fakir, M.S.A., Umaharan, P. and McDavid, C.R. 1998. A modified method for estimating abscission in pigeonpea. Trop. Agric., (Trinidad), 75(3): 393-395.

Fakir, M.S.A., Umahara, P. and McDavid, C.R. 1998a. Study of floral abscission in relation to yield in pigeonpea (Cajanus cajan (L.) Millsp). Proc. $20^{\text {th }}$ Bangladesh Sci. Conf., Bangladesh Assoc. Adv. Sci., Part-2: 119-125.

Fakir, M.S.A., Hossain, M.A., Hossain, A.K.Z., Prodhan, A.K.M.A. and Afsaruzzaman, S.M. 2000. A study of flower production and abscission in country bean (Lablab purpureus). Bangladesh J. Agric. Sci., 7(2): 279-285.

Fakir, M.S.A., Mondal, M.M.A., Ismail, M.R. and Ashrafuzzaman, M.A. 2011. Flowering pattern and reproductive efficiency in Mungbean. Int. J. Aric. Biol., 13:966-970.

Ferranti, F., Frenquelli, G., Romane, B. and Hampergher, F.M. 1994. Relationship between flowering and seed set in winter rapeseed. Agric. Miditeragea, 124(4): 249-255.

Islam, A. 2006. Study of some morphological characters and yield in mustard. M.S. thesis, Dept. Crop Bot., Bangladesh Agric. Univ., Mymensingh. p. 2-3.

Khalid, A.N.M. 1999. Floral abscission and reproductive efficiency in summer and winter tomato (Lycopersicon esculentum Mill.) varieties. M.S. Thesis, Dept. Hort., Bangladesh Agric. Univ., Mymensingh. p. 29-31.

Khatun, M. 2004. Study of canopy structure and flower production in mustard. M.S. Thesis, Dept. Crop Bot., Bangladesh Agric. Univ., Mymensingh. p. 9-13.

Miri, H.R. 2008. Morphophysiological basis of variation in Rapeseed (Brassica napus L.) Yield. Int. J. Agric. Biol., 9(6): 845-850.

Özer, H., Erol, O.L. and Ünsal, D. 1999. Relationships between yield and yield components on currently improved spring rapeseed cultivars. Trop. J. Agric. Forestry, 23: 603-607.

Shil, R.K. 2005. A study of growth, dry matter production and yield in fifteen mustard genotypes. M.S. Thesis, Dept. Crop Botany. Bangladesh Agric. Univ., Mymensingh. p. 29.

Shingh, R.K. and Choudhury, B.D. 1985. Biometrical methods in quantitative genetic analysis. Kalyani Pub., New Delhi, India.

Tayo, T.O. and Morgan, D.G. 1975. Quantitative analysis of the growth, development and distribution of flowers and pods in oilseed rape (Brassica napus L.). J. Agric. Sci., (Camb.) 85: 103-110.

Thurling, N. 1974. Morphophysiological determinates of yield in rapeseed (Brassica campestris \& B. napus). II. Yield components. Australian J. Agric. Res., 25: 711-21.

Tunçtürk, M. and Çyftçi, V. 2007. Relationships between yield and some yield components in rapeseed (Brassica napus ssp. oleifera I.) cultivars by using correlation and path analysis. Pak. J. Bot., 39(1): 81-84. 